Polgári Szemle, 16. évf. 4-6. szám, 2020, 51-66., DOI: 10.24307/psz.2020.1005

\author{
Botos Katalin
}

\title{
A koronavírus-válság és a világ régiói
}

\section{The Coronavirus Crisis and the Regions of the World}

\section{Összefoglalás}

A tanulmány megállapítja, hogy a bóség társadalmának más gazdaságelmélet felel meg, mint a szúkösség társadalmának. A keresleti válság már korábban is szükségessé tette a pénzteremtést a vásárlóerô rendelkezésre állásának céljára. A koronavírus okozta válság rámutatott, hogy nemcsak keresleti, de kínálati válság is van. Mindkét területen válságot okoznak az egészségügyi helyzet miatti termelési leállások. A termelési leállás és így a személyes jövedelmek kiesése általános. Az állami beavatkozás szükségszerú, az élet és a megélhetés biztosítása érdekében is. A tanulmány a nemzetközi szakirodalom alapján megvizsgálja a reagálásokat az USA-ban, az EU-ban és a fejlôdô országokban. Különös figyelmet fordít a költségvetés és a jegybank együttmúködésének kérdésére. Megállapítja, hogy változóban vannak a pénzelmélet dogmái.

Journal of Economic Literature (JEL) kódok: E58, H12, H5, H62, H63, H72, I38

Kulcsszavak: krízismenedzsment, monetáris politika, szuverén adósságfinanszírozás, helyi és központi költségvetés, fejlett és fejlődô országok helyzete, jog és gazdaság

\section{Summary}

The study establishes that an affluent society requires a different economic theory than an economy of dearth. Previously, demand crisis required the generation of money to make it available for purchasing power. The coronavirus has revealed, how-

Prof. DR. Botos Katalin, professor emerita, Szegedi Tudományegyetem (evmkabor@gmail.com). 


\section{Botos Katalin: A koronavírus-válság és a világ régiói}

ever, that in addition to a demand crisis, there is also a supply crisis. Disruptions in production due to the health situation cause crises in both areas. Production stops and the consequent loss of income is common. Government intervention is inevitable to maintain life and secure subsistence. Based on the international literature, the responses given in the USA, in the EU and in developing countries are analysed. Special attention is paid to matters related to the budget and to central bank operation. The study concludes that the tenets of monetary theory are changing.

Journal of Economic Literature (JEL) codes: E58, H12, H5, H62, H63, H72, I38

Keywords: crisis management, monetary policy, sovereign debt financing, local and central budgets, situation in developed and developing countries, law and economy

\section{BEVEZETÉS}

A koronavírus-válság a világ minden régióját megviseli. A tanulmányban a különbözô világrészek, országok, földrajzi egységek pénzügyi reagálását elemezzük. Azt vizsgáljuk, mennyiben tapasztalhatók általános válságjelenségek a közgazdaságban, és menynyiben térnek el a pénzügyi reakciók egymástól az egyes térségekben.

\section{VÁLTOZÁSOK ÉS VÁLSÁGOK}

Dogmák dőlnek meg a közgazdaságtanban. Tömören úgy fogalmazhatunk, hogy a bôség társadalmának pénzügyei nem azonosak a szúkösségen alapuló közgazdaságtan alapelveivel.

A termelés napjainkra olyan hatékonysági fokot ért el, és a kereslet olyan korlátozott, hogy inkább defláció van, mint infláció, hasonlóan a múlt század harmincas éveihez. Akkoriban jött az elsố komoly figyelmeztetés, hogy elérkezett a bóség társadalma, és új közgazdaságtanra van szükség. A fejlett országokban elterjedt keynesi elmélet szerint a fellendülés csúcsán keresletet kell teremteni, hogy a polgárok megvásárolják az árubőséget, aztán ki kell vonni a fölös pénzt, a gazdaság túlfútését elkerülendô. A pénzügyekben eddig gyakorlatilag két megoldást kínáltak a túltermelés problémájára: állami túlköltekezéssel nyomni többletkeresletet a gazdaságba, illetve magánbankpénz teremtésével, hitelekkel tartani fenn a fogyasztás kellô szintjét. Mindkettőre bôven találunk példát a közelmúltból, elsôsorban az Amerikai Egyesült Államokban.

Ebben az elméletben legfóképp valóban csak a fejlett országokról van szó. Hiszen nehéz lenne világméretekben a jólét túltengésérôl beszélni. Akkor, amikor nevetségesen alacsony összegekbốl él - ha megél - az emberiség egy jelentôs része. Óriási a szegénység sok afrikai országban, de Ázsiában, Indiában is. Szükséglet ugyan van ezekben a gazdaságokban, de a fizetóképes kereslet hiányzik.

A közgazdasági elméleteket nem a fejlődô országokban írják, hanem a fejlett gazdaságokban. Még a legnagyobb elmék is, akik egyáltalán foglalkoztak a szegénység prob- 
Polgári Szemle · 16. évfolyam 4-6. szám

lémájával, az USA-ban tanítják a közgazdaságtant, például a Harvardon (mint Amartya Sen $^{1}$ ). Ezért elsôsorban az amerikai gazdaság jelenségeire irányítjuk figyelmünket.

\section{Vigyázó SZEMETEK NeW Yorkra Vessétek...}

A 2008-as válság az USA-ból indult ki. Tudjuk, azt „helikopterpénzzel” kezelték. Miért volt erre szükség? Azért, mert az államokban a bérból élók helyzete nehezebbé vált az elmúlt hetven évben, különösen annak második felében. A bérek adói 1950-hez képest drámaian emelkedtek az USA-ban, míg a vállalati jövedelemadók jelentôsen csökkentek a költségvetés bevételeiben. (A vállalati profitok viszont nem csökkentek a GDP \%-ában, azaz a tôketulajdonosoknál több jövedelem maradt.) Bô harminc év óta elmaradt a bérek növekedési üteme a tôkehozadékétól. A bérszínvonal gyakorlatilag egyáltalán nem emelkedett. Így a bérból élők a viszonylag magas fogyasztási színvonalukat csak hitellel tudták fenntartani. Ugyanakkor a reklámok és a politika felkeltették az emberekben a még jobb élet vágyát, elérhetônek tüntették fel a saját otthont, mint a megvalósítható amerikai álom elemét. Különösen a választási hadjáratok alkalmával... A hitelfelvételt aztán a nagyon alacsonyan tartott kamatszinttel a Fed tovább ösztönözte, annál is inkább, mert az építôipar mindig is a gazdaság motorja volt. Így nemcsak a vállalkozóknak, de a politikusoknak is fontos a gazdaság pörgése. A pénzügyi szektor olyan magánhitelezést erôltetett, amelyet - mint utóbb kiderült - a polgárok végsô soron nem engedhettek meg maguknak. A körülmények nehezedésével ugyanis tömeges lett a lakáshitelek csódje.

Miért következett be ez a hirtelen romlás a hitelképességben? Az ok: a globalizáció. A szabad tôkeáramlás az elmúlt pár évtizedben veszélybe sodort számos amerikai munkahelyet. A vállalatok egy része kiszervezte a tevékenységét a világ dinamikusan fejlôdő és sokkal olcsóbban termelô régióiba. Így az USA bérból élố polgárai egyre nehezebben tudták visszafizetni a felvett lakáshiteleiket. Ezeket a hiteleket a pénzügyi innovációk eredményeként a pénzügyi intézmények új eszközök formájában „összecsomagolták”, és értékpapírokként továbbadták. Így azok „mérgezett termékekké” változtak, hiszen a csomag egyes elemeit az idôk során már nem tudták fizetni a hitelfelvevôk. De azt, hogy melyik csomagban mi van, nem lehetett tudni. Ezért bizalmi válság alakult ki. Lecsökkent a bankközi hitel volumene, hiszen senki sem volt biztos abban, mi rejtôzik a másik bank portfóliójában... Likviditáshiány keletkezett a bankszektorban. Röviden ebben foglalhatjuk össze a 2008-as válság okát. A megoldását pedig abban, hogy az ún. quantitative easing során a Fed unortodox módszerek bevetésével likviditást pumpált a gazdaságba, s gyakorlatilag kimentette a bajba került pénzügyi intézményeket.

És máris megtapasztalhattuk a dogmák megdólését!

Miért nem okozott a nagy pénzkiáramlás inflációt? Igaz, az is kérdés, mit nevezünk annak. Az infláció „hivatalos” mércéje a fogyasztói árszint emelkedése. Ha pedig csak a fogyasztóiárszint-emelkedést nézzük, akkor tény, hogy a pénzbepumpálás azt valóban nem okozott; de eszközárbuborékot igen!

Hogyan lehet, hogy a jegybankok, segítve az állami bankmentó akciókat, szinte korlát nélkül vásárolnak államkötvényeket, de emellett vesznek vállalati kötvényeket 
is? A központi bank tehát nem csupán a bankok bankja? Pedig ezt tanította, évtizedeken át, a pénzügytan, dogmaként. És azt is, hogy a központi bank kézben tartja - a kamatpolitika mellett - a pénzteremtés mennyiségét, hiszen a tartalékráta-politikával szabályozza azt. (Amerikában ugyan valóban van még tartalékolási kötelezettség, de Európában ezt már hosszabb ideje a minimumra csökkentették.) Széles körben elismerik azonban, hogy nem a központi bank szabályozza a rátával a pénzteremtés menynyiségét, hanem csak utánamegy a kereskedelmi banki pénzteremtésnek (Botos, 2016).

A jegybanki kamatpolitika kétségtelenül olcsóbbá tette a hiteleket, s így ösztönöz a pénzteremtésre. Nagy kérdés azonban, hogy a pénzköltés mire irányult. A hitelek sajnálatosan nem elsôsorban a reálgazdaságba irányultak, hanem az ingatlanpiaci spekulációt fútötték. Az USA-ban, mint említettük, a béremelkedések elmaradtak a profitok növekedésétôl, így a polgárok a fogyasztás szinten tartását úgy oldották meg, hogy az alacsonyabb kamatok és a megnövekedett fedezetérték miatt nagyobbra cserélték a lakásokra korábban felvett hiteleiket, a különbözetet pedig felélték. Ahogy Rajan írta, a tôketulajdonosok azt mondták: a munkavállalók „egyenek hitelt” (Rajan, 2011).

Amerikában a mainstream közgazdaságtant követő politikusok azt hangsúlyozták, hogy kevés az adóbevétel, nincs elég közpénz a Medicare kiterjesztésére, a napjainkra már komoly társadalmi problémává vált diákhitelek elengedésére vagy más, igencsak szükséges kommunális projektekre. Számos publicisztikában lehetett olvasni, hogy az infrastruktúra több helyen meglehetôsen lepusztult az USA-ban. De hát, mondták, a szövetségi költségvetés nem engedhette meg magának a felújításokat.

És akkor berobbant a vírusválság! Az amerikai kongresszus néhány nap alatt elfogadta a koronavírus elleni mentốcsomagot, a Coronavirus Aid, Recovery and Economic Security (CARES) programot. Ez mintegy 2200 Mrd dollár pénzmennyiség bepumpálását jelenti a gazdaságba, a polgároknak, de fóleg a vállalati szektornak. Ellen Brown² így fogalmazott: „a kongresszus felfedezte a pénztermő csodafát”. A Fed pedig további 4000 Mrd dollárt tett elérhetôvé a bankok, hedge fundok és más pénzügyi intézmények számára, különbözô módokon. Ismét csökkentette továbbá az irányadó kamatot, és másfél ezermilliárd dollárt biztosított a repopiac számára (Brown, 2020).

Honnan lett elegendô pénze a költségvetésnek e rendkívül nagyszabású programhoz? A 2008-as válság után az USA-ban nagy fellendülés volt, ez jócskán megemelte az adóbevételeket. A többletbevétel azonban most eltúnik. A Covid-válság várhatóan a felére csökkenti az egyes államok fó adóbevételi forrásait jelentô jövedelemadókat. ${ }^{3}$

Nyilvánvalóan a deficit, pontosabban, az államadósság növekedése terhére teremtenek pénzt. Elméletben a QE csak ideiglenes intézkedés; a Fed által teremtett pénz a papírok piacra dobásával visszaszívható. Csakhogy ez valóban inkább pusztán elméletben igaz. A pénzkivonás megkísérlése a 2008-as válságot követô idókben nyomban lehútötte a gazdaságot, és meghátrálásra késztette a Fedet. Amikor ugyanis megpróbálta az adósságállomány leépítését, a gazdaság nyomban visszajelzett, hogy nem lehetséges... A tôzsde bezuhant. Így a Fed gyakorlatilag kénytelen volt tartani a papírokat, tovább görgetni a tartozást, folyamatossá téve a finanszírozást. Tovább finanszírozta az államadósság-állományt. Nagy valószínúséggel ez történik a mostani adósságnövekedéssel is. 
A szövetségi adósságkezelés normál gyakorlatában az amerikai állampapírokat a világon széles körben vásárolják. (Többek között nagy mennyiségben a kínaiak.) Akkor azonban, ha a Fed vásárolja meg az államadósságot, egyszerúbb és olcsóbb lesz a költségvetés számára a finanszírozás. (2020 tavaszán, a vírusválság kapcsán a Fed olyan ütemben vásárolta fel - quantitative easing jegyében - a kormánypapírokat, hogy ha ilyen ütemben folytatná, két év alatt a teljes kormányértékpapír-állomány a tárcájában lenne.)

Az adósságok ugyanis a Fed felvásárlása révén gyakorlatilag lejárat nélkülivé válnak. A jegybank a mérlegében tarthatja az állampapírokat, ad graecas calendas (az idók végezetéig). A kamatokat természetesen fizetni kell, ez azonban az USA nemzetgazdasága számára nem jelent veszteséget. Amennyiben a kormánypapírok a Fednél vannak, a fizetett összeg nagyrészt visszakerül a költségvetésbe. A Fed ugyanis nonprofit intézmény, a költségei fölötti részt az év végén átutalja a kincstárnak. (Természetesen árnyalja a képet, hogy a költségeibe beleszámítja a magántulajdonosainak évente mindenképpen kifizetendô 6\%-ot is, hiszen magántulajdonosai vannak az intézménynek, noha kongresszusi szabályozás alá esik.) Így a bank költségeinek levonása utáni haszon végül a kormányhoz kerül. Ennek nagyságrendje 2019-ben - Ellen Brown idézett cikkének közlése szerint - tetemes összeget, 575 Mrd dollárt tett ki. Münchhausen báró esete forog fenn: a Fed átutalása a forrása ugyanis annak a kamattehernek, amit a költségvetés az állampapírokért fizetni tartozik a Fednek. A hitelek így gyakorlatilag kamatmentessé válnak. A rulírozás miatt végül is a hitelek lejárat nélküliek, és a fentiek miatt de facto kamatmentesek, vagyis a Fed monetizálja a deficiteket.

Íme, az együttmúködés a világvaluta jegybankja és a kormányzat között! Eddig úgy tanultuk, ez tilos. Változik a gyakorlat, és így változik az elmélet is! „New normal” lesz, normává válik, ami korábban megengedhetetlen volt.

Az amerikai központi kormány válságcsomagjának mindenesetre csak viszonylag csekély hányada szolgálja közvetlenül a lakosság túlélését. Az állami és jegybanki eszközök nagyobb része a gazdaság túlélését, a mielóbbi újraindítást szolgálja. Az arra jogosult polgárok - messze nem mindenki - kaptak egy egyszeri, 1200 dolláros segélyt a szövetségi kormánytól, és a munkanélküli-segélyeket is meghosszabbították négy hónappal. (Megjegyzendő, ez eddig az amerikai gazdaságpolitikában példa nélkül álló intézkedés.) A helyi önkormányzatoknak az elsố csomagban csupán 150 Mrd dollár válságsegély jutott. A szövetségi fiskális politika a lokális önkormányzatokat arra késztette, hogy elsôsorban maguk segítsenek magukon. Az esetleges - és nyilván még szükséges - önkormányzati kötvénykibocsátásokat pedig majd megvásárolja egy létrehozandó speciális pénzügyi intézmény.

A kifelé egységes állami arculattal jelentkezô USA 50 államból áll. Az egyes államok önálló jogalkotással, költségvetéssel rendelkeznek. A szövetségi kormányzat csak azokban a tételekben hozhat törvényeket, amelyeket az alkotmány felsorol. Az egyes tagállamok bevételeinek nagy része saját törvényhozásuktól függ. (Az államok költségvetési helyzetét a közelmúltban két dolog befolyásolta: a 2008-as válság, ami, mint utaltunk rá, megcsapolta a bevételeiket, és ezzel ellentétesen, növelte bevételeiket a kapott költségvetésitámogatás-többlet.) A bevételekben a szövetségi kormányzattól ka- 
pott támogatás 2016-ban 32\%-ot tett ki. Ez döntôen a Medicaid kiterjesztése miatt jelentkezett, amelynek következtében az egyes államok többlettámogatásokhoz jutottak a központi kormányzattól. A Medicaid jelenti a szövetségi támogatások kétharmadát. A Medicaidhez bejelentkezôk száma 2008 és 2018 között erôsen, majdnem 60\%-kal megnövekedett.

Abban az esetben, ha a válság miatti hiányokat az önkormányzatoknak hitelfelvétellel kell megoldaniuk, komoly gond jelentkezik. Nekik ugyanis - szemben a központi költségvetéssel - mindenképpen számolni kell a kamatteherrel, hiszen az önkormányzatoknak nem utal vissza a hasznából a Fed, illetve a létrehozandó speciális intézmény, a special purpose vehicle (SPV) úgy, mint a költségvetésnek a föderális értékpapírok vásárlása után. (Hacsak nem hoznak létre maguk az egyes államok is saját lokális közösségi bankot, amely élhetne a haszon visszautalásával az önkormányzatok felé. Legalábbis ezt a megoldást javasolja Ellen Brown idézett publikációjában.)

Néhány szóban térjünk ki az elóbbiekben említett speciális intézmény, az SPV szerepére! Az SPV valójában egy árnyékbank: az értékpapírokat pénzzé változtatja, amelyek bármilyen fizetésre felhasználhatók. Ehhez korlátlan finanszírozást kap a Fedtől. Az egyetlen korlát, hogy nem vásárolhat tôzsdén jegyzett részvényeket és junk bondokat. A Fed a szabályai szerint csak állami garanciákkal bíró értékpapírokat vehet, állampapírt, jelzáloggal fedezett, kormányügynökségek által kibocsátott papírokat, a Fannie May és Freddie Mac papírjait, és - esetleg - önkormányzati kötvényeket. Utóbbinál azonban kérdéses volt az állami garancia. Ennek a problémának a megoldására szolgál a Fed által a költségvetéssel közösen finanszírozott SPV.

A szövetségi költségvetés, a Treasury 425 Mrd dollárral „beszáll” az SPV alaptôkéjébe. Ezt a Fed tovább finanszírozza. Így az SPV akár 4-5 ezermilliárdot kitevô eszközállományt is megmozgathat. A kérdés az, mekkora lesz az innen továbbadott kölcsönök kockázata. Nyilván az a megfontolás húzódik meg a konstrukció mögött, hogy a hitelek kockázata a tőke mértékéig mindenképpen a kincstáré. Becslések szerint az esetleges veszteségek várhatóan nem haladják meg a költségvetési beszállás mértékét. (Tehát a finanszírozó Fedet nem érheti jelentôsebb veszteség.)

Szemben azzal, amikor a Fed vásárolt kormányzati értékpapírokat, és azt a mérlegében tartotta, jelen esetben valójában a kincstár, a Treasury vásárol értékpapírokat az SPV-n keresztül, amelyet kontroll alatt tart, de a Fed finanszírozásával. Bizonyos értelemben a Fed így lehetôséget ad a kincstárnak a pénznyomáshoz való hozzáférésre. A Fed és a kincstár ilyen szoros együttmúködése egyfajta államosításként is felfogható. Legalábbis egyes elemzôk így vélekednek. ${ }^{4}$

Ez a konstrukció most a vírus elleni küzdelmet szolgálja, de bármikor felhasználható más célra is, adott esetben a piac befolyásolására, egy választási kampány idején... (Ma még nincsenek ilyen SPV-k, de elvileg létrehozhatók.) Vagy például a régóta esedékes infrastrukturális projektek finanszírozására, a Medicare kiterjesztésére, alapjövedelem adására, esetleg a diákhitel-adósságok enyhítésére - amire eddig, mint utaltunk rá, nem volt pénz. Sót ily módon az állam akár bizonyos bajba került bankokat vagy gyógyszergyárakat, olajtársaságokat, esetleg más cégeket is megszerezhet, és a közérdek szolgálatára átállíthatja óket. 
Jog ÉS GAZDASÁG

Álljunk meg itt egy pillanatra! Feltaláltuk a szocialista kapitalizmust? Azt a rendszert, amelyben állami vállalatok közérdeket szolgálnak, jegybank vagy közösségi tulajdonú bankok által finanszírozva? Mint egykor, a tervgazdaságban? (Az összehasonlítás nyilván sántít, mert a szocialista tervgazdaság diktatúra közepette múködött. A modern fejlett világban azonban elméletileg demokratikusan választott kormányok léteznek.)

A „kis államot” szorgalmazó gazdaságpolitikai elméletekbe eddig nem fért bele az állami tulajdonú vállalkozások léte a versenyszférában. Európa pénzügyi szektorában például, éppen a piacgazdaságra hivatkozva, komoly gondot jelentett az állami (tartományi) tulajdonban lévố Landesbankok megléte. Azt mondták a versenytársak, hogy a német Landesbankok fölötti állami, tartományi tulajdoni garancia versenyelônyt jelent számukra. Az EU törvényhozása a versenysemlegességre hivatkozva e banki jogállás megszüntetését szorgalmazta.

Sajnálatos módon mégiscsak bajba kerültek ezek az intézmények is, mert bevásároltak az ún. mérgezett amerikai eszközökból. Meglepetést is jelentett 2008 után a német államnak, hogy valóban élnie kellett bankmentô eszközökkel. Korábban - szemben az USA tapasztalataival - a német bankrendszerben nem voltak komoly problémák. Általában a bankfelügyelet kivezette a piacról a kevés, bajba került intézményt még az elótt, hogy komolyabb veszteséget jelentett volna a csődjük a betéteseknek vagy az államnak, illetve a betétbiztosítónak. Csakhogy a nagy amerikai banki konglomerátumok világméretekben terjesztették mérgezett „termékeiket”, és behatoltak ezekbe az egyébként szolid üzleti körökbe is. A Landesbankokat éppúgy jól fizetett menedzserek vezették, mint a többi kereskedelmi bankot, s ók eredményt akartak produkálni. Így a tulajdonosi szerkezet sem mentette meg e köztulajdonban lévó bankokat a 2008-as válság kellemetlen hatásától.

Igaz, 2008-ban az amerikai bankrendszert is ki kellett mentenie a szövetségi államnak, hiába volt a pénzügyi intézményrendszer döntôen magánalapon szervezett. Ebból azért látható, hogy nemcsak a köztulajdonban lévô, de a magánalapú bankvállalkozás sem garancia arra, hogy a rossz döntések minimalizálhatók.

Témánk szempontjából az a döntố kérdés: Meghatározhatja-e vajon egy demokratikusan választott kormány, hogy mikor vegyen állami kezelésbe versenycégeket? Mit tekint közérdeknek? És annak finanszírozására felhasználhatja-e a vele együttmúködő központi bankot? Lehet-e az állam magánjogi alapon tulajdonosa a bankoknak (esetleg gyógyszergyáraknak vagy más, nemzetbiztonsági szempontból fontos cégeknek)? A 2008-as válság kapcsán az USA-ban elfogadottá vált, hogy a bankok kimentése nemzetbiztonsági jelentôségú. Ezért Amerikában kimentették az AIG biztosítót, és „conservatorship" alá vonták például a Fannie May-t és Freddie Macet, az állami garanciával bíró jelzálogintézményeket. Ezek a hatalmas cégek valóban rendkívüli fontossággal bírnak a jelzálogpiac tekintetében. Utóbbinak a mérete csaknem feleakkora, mint az állampapírpiacé. A „conservatorship” azt jelenti, hogy az állam beszáll a magántulajdonban lévô intézmények tôkéjébe - így fedezve a veszteségeket -, s ennek fejében korlátozza a tulajdonosi jogaik gyakorlását, továbbá igényt tart az intézmények 
múködésének hasznára. Mindez de facto tulajdonjog, tehát gyakorlatilag ideiglenes államositást jelent. Igaz, a kormánysegítség „ledolgozása” után visszakaphatták jogaikat az eredeti tulajdonosok. A vírusválság alkalmával most, Amerikában ismét felvetôdtek olyan javaslatok, hogy a válság elleni küzdelemben szükségessé válhat vállalatok állami irányítása, mint háborús helyzetben, vagy rendkívüli állapotok kihirdetése esetén. Erre azonban egyelőre nem került sor.

Mindenesetre a válság megmutatta, hogy minden lehetséges, ha a társadalom úgy akarja... Jog és gazdaság szorosan összefügg. A pénzügyi szabályok nem az égból kerültek alá, kốtáblákon, ezeket a jog alakítja, amely mögött viszont markáns társadalmi csoportok érdekei húzódhatnak meg. Az a kiadás lesz költség, amit a jog annak tekint; $\mathrm{s}$ az a vagyon lesz tôke, amelyet a jog azzá tesz.

Katharina Pistor, a Columbia Law School tanára rámutatott: a jog képes tókét teremteni (Pistor, 2019). Tókévé tud alakítani vagyontárgyakat, jogviszonyokat, megvédve azok tulajdonjogát másoktól, s felhasználásukat olyan díjfizetéshez kötni, amely a tulajdonosoknak jövedelmet termel. Ezáltal a vagyonból tôke lesz. A kapitalista piacgazdaságban a jog az állam hatalmát maga mögött tudva, fizikai és szellemi javak tôkeként való múködését teszi lehetôvé (lásd pl. szabadalmak). A jog biztosítja a banki hitelezôk és az állam előnyét a csődeljárásokban, a jelzálogok érvényesíthetôségét, a pénzügyi intézmények múködési szabályainak kialakítását. Az állam, ha kell, kényszerító eszközökkel áll a jogszabályok mögött..

Ugyancsak a jog ad keretet a banki pénzteremtéshez is, és szabja meg a jegybanki múködés szabályait. Adair Turner, a Bank of England bankfelügyeletért felelôs egykori vezetóje 2016-ban könyvet írt ez utóbbi kérdésrôl (Turner, 2016). Rámutatott: a korábbiakban az elmélet azt mondta, pénzt csak a bankok teremthetnek. Az állam általi pénzteremtést valami ördögi dolognak tartotta. A mainstream elmélet szerint a jegybankon kívül, azt multiplikálva, csak a magán kereskedelmi bankok tudnak pénzt teremteni, azon egyszerú módszerrel, hogy a könyvelés szabályai szerint egyszerre helyeznek egy összeget mérlegük eszköz- és a forrásoldalára. Ha a kereskedelmi banki pénz kikerül a banki klíringkörból, akkor természetesen már a jegybank által teremtett pénzre van szükség. (Érdekes, hogy valamennyi központi bank kutatógárdája ugyanazon idóben érezte szükségét, hogy rámutasson a mindennapi tényre, a magánpénzteremtésre. 2014-2015-ben sorban jelentek meg cikkek a témáról a Bank of England, a Fed és a Bundesbank bulletinjeiben, s nagyjából ugyanakkor a magyar sajtóban is (Botos, 2016). Természetesen nem maga a tény volt újdonság, csak az a kérdés, hogy ki és mi jelenti a pénzteremtési tevékenység korlátját. Hiszen a pénzelmélet abból indult ki, hogy a túlzott pénzmennyiség inflációt okoz, így káros a gazdaság számára, ezért keretek közt kell tartani. Úgy vélték, a kereskedelmi banki pénzteremtés ennek gátját tudja vetni, a jegybanki korlátozásokkal meg különösen. Az állam viszont lehet felelôtlen.

Turner világossá tette, hogy a nyakló nélküli állami költekezés valóban nemegyszer okozott inflációt a történelem során, és ezáltal válságokat is. Ugyanakkor az is tény, hogy a felelôtlen magánbanki pénzteremtés ugyanúgy eredményezhet válságot, hiszen a magánhitelezés „elszaladása” volt a 2008-as válság oka. Ezt nem lehet az állami túlköltekezés számlájára írni. 
Joggal teszi fel Turner a kérdést: Akkor mi a lényegi különbség a két megoldás között? Nyilván az, hogy milyen célokra használják fel a pénzteremtés lehetôségét. Garantálható-e a kormány esetében, hogy a pénzteremtés valóban kizárólag fontos közcélokat szolgál? Biztos-e, hogy a magánérdeket követô kereskedelmi bank, élve a jog adta lehetôséggel, mint a piac láthatatlan keze, valóban csak hasznos, a közösség érdekét szolgáló célokra ad-e majd hitelt? A kérdés valóságos, és a válasz nem egyértelmú. Nem az állami címke tesz valamit közérdekké. Közösségi érdek lehet adott esetben olyan magánérdek követése, amelynek esetében a meghitelezett termék, szolgáltatás előállítása valóban a széles közösség jólétét emeli. De azért nem minden magán-hitelkereslet kielégítése teljesíti ezt a kritériumot. A hitel iránti kereslet megléte nem feltétlen garancia a közérdekú hasznosságra! A bankokhoz ugyanis - pl. az ingatlanüzlet felfutásakor - lehetett spekulációs céllal is hitelért folyamodni, és ameddig az „ingatlanlufi” ki nem durrant, ez a kérelem akár „jó hitelkérelemnek” is tûnt. A pénzügyi intézmények kicsinek vélték a kockázatot, a „tail risk”-et. Garantáltnak látszott a felvett összeg visszafizetése, olyan nagy volt a kereslet az értékpapírosított hitelek mint befektetési termék iránt. A bankok - noha alkalmaztak jól megfizetett kutatógárdát a kockázat felméréséhez - nem érzékelték a makroszintú problémát, így nem tudták kivédeni a 2008-as válságot (Turner, 2016).

Egy azonban biztos: ha a kereskedelmi bankok teremtik a pénzt, a haszon döntô része bizonyosan náluk marad. Ez igen nyomós érv a kereskedelmi banki lobbik számára a pénzteremtés előjogának további fenntartásáért folyó küzdelemben.

Most itt van a vírusválság. Aligha lehet kétséges, hogy a válság elleni harcban a pénzteremtésnek közérdekú célja van (vagy legalábbis lehet). Vajon jelenleg hogyan ítélhetjük meg a fenti kérdést? Ki teremtsen pénzt?

Hosszú idôn keresztül úgy lehetett feltüntetni a magánpénzteremtést, mint ami a piac spontán múködésének eredménye. Amikor azonban a gépezet akadozni kezdett, a pénzügyi intézmények mindig megtalálták a módját, hogy az állam segítségéért folyamodjanak. A hatalom - lássunk világosan - a demokráciákban is a vagyonos csoportok kezében van, ezt Joseph Stiglitz számtalan munkájában bemutatta. ${ }^{5}$ A modern demokráciákban ugyan folyamatosan ápolják azt az illúziót, hogy a „shoeshine boy” is válhat milliomossá, de azért ez inkább csak mese. Nem minden átlagember válhat vagyonossá, sốt. Így pedig a hatalom gyakorlásához sem férhet hozzá úgy, mint az a bizonyos felsô $1 \%$.

Tény, hogy ma már minden egyes polgár a szavazóurnákhoz járulhat. De hogy mit válasszon, azt nagyban befolyásolja a média. Az is meglehetôsen közismert, hogy milyen manipulációs eszközök állnak a politikai erôk rendelkezésére. Nagy információs különbségek léteznek a szavazók szuverenitása között, amit végsố soron befolyásol az anyagi helyzettôl nem független múveltségi szint is. A választási hadjárat gyakran pénzkérdés Amerikában; a felhasználható anyagi eszközöket többnyire törvény szabja meg. A 20. század elején Amerikában még a jog korlátozta a vállalatokat a választási támogatások mértékében, ezt azonban a közelmúlt törvényhozása eltörölte. Stiglitz úgy fogalmazott, hogy Amerikában manapság nem az „egy ember, egy szavazat”, hanem az „egy dollár, egy szavazat” elve érvényesül (Stiglitz, 2015). Így olyan törvényhozók kerülhetnek a hatalomba, akik továbbra is képesek biztosítani, hogy az érdekcsoportjuk- 
nak megfelelóen alakuljanak a szabályozások. Számtalan példát lehetne erre hozni, de elég csak a banktörvények körüli amerikai fejleményekre utalni. Raghuram Rajan a nagy pénzügyi válság után készült sikerkönyvében javaslatot tett a bankméretek törvényi redukálására (Rajan, 2011). Ne lehessen arra hivatkozni, hogy egy-egy bank „too big to fail”! Mi valósult meg ebból? Semmi. Ellenkezóleg, a bankkoncentráció csak erősödött 2008 óta. Még azt a törvényt is fellazították az USA-ban, amelyik a válság után született a szektor kockázatainak csökkentésére (Dodd-Frank). Az állam tehát soha nem pusztán „éjjeliôr” a kapitalizmusban, hanem a gazdaság múködési feltételeinek alapvetố meghatározója, a szabályok alakítója. A jog nemcsak a magántulajdonon alapuló gazdálkodási rendszer sérthetetlenségét biztosítja, de aktívan hozzá is járul a fennálló társadalom jövedelmi különbségeinek újratermelôdéséhez.

\section{ÉS HA VIGYÁZÓ SZEMÜNKET BRÜSSZELRE VETJÜK?}

A jog és gazdaság összefüggése még bonyolultabb az európai integrációs viszonyok között.

Európában kezdetektôl fogva két elképzelés ütközött: a nemzetállamokon alapuló összefogás és az Európai Egyesült Államok gondolata, amelyet Jean Monnet képviselt. Mind a mai napig birkózik ez a két koncepció. A különbséget érdemben kifejteni „szoroska hely az itteni" (Arany János). Itt csak néhány mozzanatra hívnám fel a figyelmet.

Az amerikai államok között van közös elvi platform. A mai napig összekötő kapocs a kereszténység. ${ }^{6}$ Társadalmi berendezkedésben Észak és Dél államai között ugyan voltak jelentôs különbségek a 19. század végéig, ezt azonban a polgárháború eltörölte. És bár nincs deklaráltan hivatalos nyelv a legtöbb amerikai államban, azért a gyakorlatban mindenütt az angolt használják. Közös a valutájuk, a dollár, és a hadseregük, a külpolitikájuk, de legfôképpen: jelentốs a föderális költségvetésük mértéke.

Európában viszont más a helyzet. Sok évszázados, évezredes hagyományokkal bíró, eltérô nyelvet beszélô, eltérô kulturális örökséggel rendelkezô jogi egységekrôl van szó. A 20. századig a mai Európa országainak lakosságát is döntôen keresztény (katolikus és protestáns, s részben ortodox felekezetû) közösségek alkották. Egyes államaiban a lakosság többsége ma is ezt a vallást jelöli meg a felmérések, népszámlálások alkalmával. Az EU alaptörvénye azonban a keresztény gyökereket nem sorolta az EU örökségei közé. Holott ez nagymértékben erősíthette volna a közös kulturális bázist, hiszen minden másban jelentősek a különbségek. A gazdasági közösségként induló integráció számos tekintetben nem fejlődött politikai integrációvá, föderális közösséggé. Nincs közös hadserege, és a szándék ellenére valutája, az euró se minden tagállamban használatos. A legnagyobb különbség azonban a központi költségvetés és az egyes államok költségvetésének igencsak eltérô mértéke. A szövetségi költségvetés az USA-ban az összes állam költségvetésének többszöröse. Európában ezzel szemben az EU költségvetése a 2\%-át sem éri el a tagállamok összesitett költségvetésének. Az átlag EU-s állampolgár 240 eurót fizet be évente a közös költségvetésbe, alig többet, mint napi egy kávé értéke. ${ }^{7}$ Ennek egyértelmú a következménye: a legfontosabb kötelezó közszolgálati funkciókért nem a közösségi, hanem a nemzeti költségvetések, így azok kormányai felelnek. 
(Egyébként az EU-nak a francia államapparátus felénél kisebb adminisztratív személyzete van. Igaz, a feladatköre sem olyan kiterjedt, mint egy nemzeti költségvetésnek.)

Az USA-ban a közszolgáltatásokat a központi költségvetés finanszírozza. Az egészségügy és a nyugdíj kérdései ott a közösségi költségvetés körébe tartoznak, az osztja le a támogatást az egyes államoknak. Európában ezek nemzeti hatáskörben vannak, eltéró rendszerekben. Ami a hadi kiadásokat érinti: az USA-ban a katonai költségvetés a kötelezô funkciókon felüli föderális kiadások felét teszi ki, több mint 600 Mrd dollárt. Ez hatalmas összeg: az USA a világ legnagyobb hadseregét tartja fenn.

Európában 1985-ben még a közös költségek 70\%-a mezôgazdasági támogatásokra ment. Ma ez kb. már annak csak a fele. (Annyi biztos: az agrártámogatások következtében Nyugat-Európa már régen elérte a világtól e téren való függetlenséget. Megjegyzendô: a 2004-ben csatlakozó országok másodrangúak voltak, hiszen kezdetben kevesebb támogatást kaptak, mint az eredeti vagy korábban csatlakozott tagok.) Jelenleg a közös pénzek alapvetően beruházási célokra fordítódnak. Az EU-ban minden ország nyelve hivatalos nyelvnek számít (Sokat is költ fordításra az Unió, bár ez nem több, mint fejenként évi 2 euró.) Dokumentumait általában angol nyelven fogalmazzák, az adminisztráció is ezt a nyelvet használja.

Közismert, hogy a nyelv jelentôs gondolkodási struktúrát is magában foglal. A nyelvi különbözóség kulturális különbözóséget is takar. Az identitásnak mindig fontos eleme az anyanyelv. Az európai államokban - ámbár mindenütt tanítják az angol nyelvet - az oktatás alapja feltétlenül az anyanyelv. (Kivéve ott, ahol többnyelvú, többnemzetiségú uniós országokban, az európai tagság ellenére, még mindig hátráltatják, sốt büntetik a kisebbségek anyanyelvhasználatát. Nem is érthetô, hogyan túrheti ezt az emberi jogokra olyan érzékeny EU.)

Európai polgár olyan mértékú azonosságtudatot, mint az amerikai, semmiképpen nem mondhat magáénak (Amerika számos államában a kisiskolások szívükre tett kézzel minden reggel elmondják a hitvallást arról, hogy ók az amerikai zászló által képviselt ország húséges polgárai) (Stiglitz, 2013). Eléggé távol vagyunk még attól az integráltságtól, amelyet az Egyesült Államok elért. S ami ahhoz kellene, hogy Európában egy nemzetek feletti, föderatív állam jöjjön létre.

Mindezt figyelembe véve, mit tudott tenni az EU a jelen állapotában, mint közösségi intézmény, a koronavírus elleni küzdelemben? (Mindenesetre csak kiegészítésképpen ahhoz, amit a nemzetállamok tesznek.) Két dologról van szó. Elsôdleges követelmény az emberéletek veszélyeztetésének mérséklése, a másodlagos: megoldást kell találni arra, hogy a leállások miatt az emberek megélhetés nélkül maradnak. Tenni kell a járvány ellen, de az emiatt szükségessé váló intézkedések, a távolságtartás következtében bekövetkezett gazdasági visszaesés ellen is. Különösen a leginkább érintett ágazatokban, amilyen például a turizmus. Egyrészt azonnali segítséget kell adni az egészségügyi szervezeteknek, intézményeknek, az egészségügyben dolgozóknak, hogy teljesíteni tudják a feladataikat. Másrészt a leállások miatt jövedelem nélkül maradt embereknek a minimális megélhetést kell biztosítani. „Lives and livelihoods” - ahogy az angol nyelvú publicisztikában idézik (The Economic Times, 2020). Vagyis, az élet mellett a megélhetést is segíteni kell. Gazdasági perspektívában is kell gondolkodni! 
A gyors segítség jegyében Brüsszel számos lazítást, átcsoportosítást tett lehetôvé, már a jelen kereteken belül is. Érzékelhetô volt azonban, hogy a gazdasági probléma mértéke minden korábbinál nagyobb, ezért átfogóbb tervre van szükség. Az európai integráció erre tett egy kísérletet május végén. ${ }^{8}$ Az Európai Bizottság elnöke, Ursula von der Leyen úgy fogalmazott, hogy a válság okozta kihívást lehetőségként kell kezelni, amely módot ad stratégiai fontosságú reformkezdeményezésekre. Nem csupán a válság kezelésére, de a jövóbeni válságok elkerülésére is alkalmas változtatásokat kell végrehajtani.

Az általa előterjesztett tervezetet egyfajta New Dealként kezelve, „Green Deal'-nek nevezik. Ezzel egy csapásra több dolgot is szeretnének elérni: egészségesebb környezetet biztosítani, a digitális átállást segíteni, beruházásokkal új munkahelyeket teremteni s a megújuló energiák áttörését elérni. A jövơbe történő beruházásokra koncentráló és egyben munkahelyteremtố elképzelés $A z E U$ jövố generációja (EU next generation) nevet viseli, és fó célként a „zöldítés” programját határozza meg.

A terv megvalósításához azt tervezték, hogy átmenetileg felemelik a Bizottság saját forrásainak plafonját, az EU bruttó nemzeti jövedelme 2\%-a mértékéig. Oly módon, hogy a Bizottság élve a rendkívül erôs hitelminôsítésével, 750 Mrd euró értékben hitelt vesz fel a pénzpiacokon. Hasonló múveletre korábban is sor került, az EU-szerzôdés 122. §-a alapján, a pénzügyi válság idején. Ez a forrása az EU ún. SURE intézményének is, amelyet arra a célra hoztak létre, hogy az uniós országok ideiglenes munkanélküli-támogatási rendszereket építhessenek ki a vírusjárvány miatt elbocsátott emberek számára. De ilyen méretekben még soha nem merült fel az alkalmazás gondolata.

Végül is a konkrét mértékek a júliusi EU-csúcs maratoni vitáinak eredményeképpen lényegesen megváltoztak, hiszen mindvégig igen nagy volt a különbség az egyes tagországok hozzáállásában. A svédek, dánok, osztrákok és hollandok csak a hitelként való továbbadást tartották elfogadhatónak. A spanyol kormány által vezetett csoport elképzelései tavasszal - a másik oldalról - a javaslaton messze túlmenóen, az összeg kétszeresét is elképzelhetônek tartotta volna, kifejezetten juttatásként, a közösen felvett hitel terhére (EP, 2020). Maga a bizottsági alapjavaslat a felveendó hitel nagyobb hányadát szánta támogatásnak, s kisebb részt, 250 Mrd-ot kívánt hitelként továbbadni. Ezt a „fukar négyek” nem fogadták el, úgy vélték, sérülne az arányosság elve a kapott szolgáltatások és a befizetések értéke között. A júliusi csúcson végül is kompromiszszumban sikerült megállapodni. A végsố arányok 360 Mrd euró kölcsön és 390 Mrd euró támogatás lett (Portfolio.hu, 2020). A takarékos országok engedményt kapnak majd a befizetéseiknél, ezzel közelítve az arányosság elvéhez.

A tervek szerint programokon keresztül becsatornázzák majd a forrásokat a rászoruló gazdaságokba. A hiteleket a jövóbeni költségvetésekból törlesztenék 2028 és 2058 között. Ehhez majd értelemszerúen megfelelô közös források, feltehetôen újabb befizetések, EU-szintû adónemek lesznek szükségesek. Mindenesetre módosítják majd az államok költségvetése és a közösségi költségvetés arányait. Azzal, hogy a javaslat a törlesztés idejét erősen kitolja, módot ad a kérdés alapos megvitatására, a megfeleló formák megtalálására. Ugyanakkor már most segítség lenne a rászorulóknak.

Az egyik „csatorna” a REACT-EU program, amely a helyreállítást segítő beruházásokat takarja. Ez kiegészítésképpen jelenik meg az európai regionális fejlesztési alap és 
az európai szociális alap 2014-2020-ra tervezett forrásaihoz, ideértve a legszegényebb országoknak nyújtott segélyek alapját is. Egyértelmúen többletpénzt jelent az eddigi forrásokon felül, az érvényes keretek felülvizsgálásához kapcsolva, és nem jelentheti a jövôbeni források csökkentését, hanem a 2021-2027-es tervezési idôszak forrásai fölötti összeget foglal magában (EC, 2020). Felhasználási területei a zöldítés, a digitalizálás és a gazdaság rugalmas ellenálló képességének fokozása lesznek: az állások megtartása, a kis- és középvállalkozások múködô tôkéjének megtámogatása, az önfoglalkoztatók segítése, munkahelyek kreálása, különös tekintettel az ifjúsági munkanélküliség csökkentésére. A megfelelő felhasználási területek megtalálásának módszertana nyilván nem lesz egyszerú feladat. Úgy túnik mindenesetre, hogy az ifjúsági munkanélküliség az egyik legfontosabb mutató lehet a szétosztásnál. A vidékfejlesztés is részesül többletpénzben: a farm to folk, tehát a „birtokról az asztalra” program például az egészséges biotáplálkozás elôsegítését szolgálná. Fontos cél lesz a magánberuházások ösztönzése is, és a válság tanulságaképpen szánnak összegeket az egészségügy fejlesztésére, az egészségügyi kutatások támogatására. A globális kitekintés jegyében a humanitárius segélyeket is növelik.

Ha az EU lépését összehasonlítjuk az USA gyakorlatával, látható a fontos különbség. Az USA-ban a föderális államadósságot felvásárolja a Fed. Európában a brüsszeli bizottság pénzpiacokról vesz fel hitelt, nyilván a szabályzatokban megfogalmazott inflációs félelem miatt, ami tiltja a költségvetési papírok monetizálását. A Fed megteheti, a Bank of Japan megteheti. Az ECB nem.

Mindenképpen elgondolkodtató, hogy az EU-szerződés merev költségvetési szabályai éppen azokban az országokban nem engednek meg költségvetési lazítást, amelyekben a legnagyobb szükség lenne rá. 2020 márciusa után az USA kormányzata a GDP 14\%-át kitevố pótlólagos költekezést valósított meg. Japán 21\%-ot, Ausztrália 10\%-ot, Kanada 8,4\%-ot. Európában országonként lényegesen kisebbek és nagyon változatosak az arányok: Olaszország 1,4\%, Spanyolország 1,6\% pótlólagos kiadást tudott fordítani a vírusválság elleni küzdelemre, Németország és Franciaország 4,9-5,0\%-ot. Rendkívül fontos lesz ezért a közös források segítségével segíteni a nehezebb helyzetben lévô országokat. S az is, hogy ezt az alkalmat össze kell kötni a struktúrapolitikai változásokkal.

\section{ÉS A FEJLŐDô ORSZÁGOK?}

A felzárkózó országok a G20-on belül csak átlagosan 3\%-ot tudtak felmutatni a mobilizált védekezési források terén, a fejlettek átlagos 11\%-ot meghaladó „mozgósításával” szemben. (A szórás nagy, mert Dél-Afrikának például 10\%-ot sikerült mozgósítania.) Indiában viszont - bár Modi miniszterelnök egy 10\%-os csomagról beszél - valójában a friss pénz csak 1\%. A többi átcsoportosítás, korábban eldöntött kiadások átnevezése. A G20-on kívüli többi fejlôdô országnak azonban még minimális költségvetési lehetôsége is alig van (Ghosh, 2020).

Mindez a hosszú ideje fennálló szisztematikus világgazdasági aránytalanságok eredménye. Azok a fejlődó országok, amelyek külföldi kölcsönökre szorulnak, kis fiskális mozgástérrel sem rendelkeznek. Sokan szorgalmazzák ezért az IMF újabb SDR-kibo- 
csátását, hogy valamennyire lélegzethez jussanak azok a gazdaságok, amelyeket többnyire hatalmas felhalmozódott adósság nyomaszt. Az afrikai országok - Jayati Ghosh hivatkozott tanulmánya szerint - többet költöttek összességükben adósságszolgálatra, mint egészségügyre. Még a hazai valutában kibocsátott állampapírjaiknak is a bố negyedrésze külföldi kézben van, nem beszélve az eleve devizában denominált adósságokról. Egy részük az adósságszolgálat teljesítésének a határán van, de amelynél nincs ilyen helyzet, az is retteg a tókemeneküléstól.

A válság kitörése óta már 100 Mrd dollár hagyta el ezeket a fejlődó országokat. Ebben nemcsak a külföldiek pénze, de a saját polgáraik pénzvagyona is benne van, hiszen a liberalizálás, amit a nemzetközi intézmények tanácsára megvalósítottak, lehetôvé teszi a saját valuta átváltását és kivitelét. Várható, hogy az amúgy is eladósodott fejlôdô országokban a koronavírus-válság után újabb szuverén adósságválság bontakozik ki. Egyébként a fejlődő országok legnagyobb egyéni országhitelezôje Kína. A kieli Institute for World Economy becslése szerint a fejlődó és felzárkózó országok mintegy 380 Mrd dollárral tartoznak Kínának. Ezek a hitelek gyakran kereskedelmi projektekhez kötődnek, piaci kamatokkal és kikötött biztosítékokkal, fedezetekkel. Összehasonlításképpen: a Párizsi Klub összes országa felé fennálló adósságuk 246 Mrd dollár, ami ennél lényegesen kisebb (The Economist, 2020). Lehetséges, hogy Kína elfogad egy átütemezést. De az is lehetséges, hogy megragadja az alkalmat, hogy érvényesítse tulajdonjogát, rátegye a kezét a lekötött fedezetekre. Mindenképpen erósödni fog ezen országok Kínától való függése, ami a jövőben markáns változásokat hozhat a világgazdasági helyzetben.

Egyébként Indiában komoly a félelem a növekvô költségvetési hiányoktól s az így emelkedô - amúgy is magas - államadósságtól. Láttuk, hogy India nagyon szerény összegeket tudott a költségvetéséból a vírus elleni küzdelemre fordítani. Éppen azzal magyarázták a minimális költségvetési kiadásokat, hogy aggódnak az ország szuverén adósbesorolása miatt, amit az esetleges deficit rontana. Raghuram Rajan, az indiai központi bank korábbi elnöke javasolta ezért a befektetôk megnyugtatására egy független költségvetési bizottság felállítását s egy középtávú terv jóváhagyását, amely szerint a válság után a gazdaság visszatérne a korábbi adósságmértékekhez (Rajan, 2017). Ugyanakkor hangsúlyozta: az emberi életek megmentése a jelen különleges idôszakban mindenképpen fontos; megelőzi az egyensúlyi szempontokat is. Másrészrôl kifejtette, hogy lehetetlen tartósan fenntartani a gazdaság karantén miatti lebénulását. Mivel meglehetôsen jól ismeri az indiai gazdaság helyzetét, tisztában van a kormány szúkös pénzügyi lehetôségeivel. Maga sem tud most mást tanácsolni, mint a kormányzati prioritások átrendezését. De mindenképpen szorgalmazza a túlélést segítô források megtalálását, a hatóságok összefogását a NGO-kal az élelmiszersegély biztosításában, továbbá a kilakoltatások megtiltását.

A kisvállalkozások helyzete nehéz Indiában. A nagyobb vállalatok, amelyeknek a kicsik a beszállítói, fel tudnának venni forrásokat, és azt tovább tudnák adni. A bankok nehezen adnak hitelt a kisebb vállalkozásoknak, mert saját portfóliójuk romlásától tartanak. A vállalati kötvények sem jelentenek megoldást, mivel piacuk gyenge Indiában. Rajan ezért javasolja a bankok kisvállalati hiteleinél, hogy a kormányzat vállaljon 
fel bizonyos garanciát, legalább a kisvállalkozásoktól bejövô előzó évi adó mértékéig. (Logikus: hiszen ha nem maradnak talpon, akkor nem lesz ez évben adófizetés sem a részükról.) A kötvénypiac élénkítésére pedig azzal a javaslattal él, hogy bátorítsák a befektetési alapokat, a bankokat a jó minôségú kötvénykibocsátók papírjainak vételére. Legyen például lehetôség ezen kötvények repocélra való felhasználására a bankok részérôl. (Ehhez ugyan a központi bank törvénymódosításával kell számolni, de Rajan szerint a lépés célszerûnek látszik.)

Vagyis: a nemzetközi pénzügyi világban mindenütt szükségessé válik a válság hatására a merev szabályok rugalmasabbá tétele. Nem lehet, hogy a világ a saját korábbi szabályrendszerének a foglya maradjon! Ezt számosan érzékelik, de a pénzügyi közvélemény nehezen változik. A dél-afrikai pénzügyminiszter-helyettes például azt a javaslatot tette, hogy a jegybank vásároljon közvetlenül államkötvényeket. Hatalmas kavarodást okozott ezzel a gondolatával, amelyet egyébként a jeles professzor, Jayati Ghosh teljesen logikusnak és normálisnak nevezett, mivel az USA is, Japán is monetizálta a deficitjét (Ghosh, 2020).

Természetesen a külföldi valutáktól függő gazdaságokban a helyzet nehezebb, mint a tartalékvaluta országában. De látni kell, hogy mindenképpen rendkívüli idôket élünk. Rajan úgy fogalmazott, hogy India a függetlenné válás és a központi bankjának megalakítása óta a legnagyobb kihívással áll szemben. Érzékeltük, hogy az USA helyzete is rendkívüli: az 1930-as nagy válságot meghaladó munkanélküliségi adatokat produkál. Az Unió 2008-as válságból alig kilábaló országcsoportjának ugyancsak óriási kihívást jelent a mostani helyzet. Az európai mediterrán országok munkanélküliségi mutatói már eddig is tragikus mértékúek voltak. A válság is tőlük követelte Európában a legtöbb áldozatot.

\section{KöVETKEZTETÉS}

A világ nagy régiói különbözôen reagáltak - körülményeik, lehetôségeik függvényében - a vírusválságra. Látható, hogy a lokális szempontok mindenképpen elótérbe kerülnek. De az is világos, hogy csak nemzetközileg harmonizált módon tudjuk kezelni a problémát.

A természet adta kihívás mindenképpen fel kell hogy ébresszen mindnyájunkat, a pénzelmélet elemzôit, a pénzügypolitika és gazdaságpolitika irányítóit is, hogy a válság után semmiképp nem léphetünk vissza ugyanabba a folyóba. Számolnunk kell a világ megváltozott körülményeivel, és ahhoz kell igazítanunk ember alkotta szabályainkat, gazdasági elméleteinket és gazdaságpolitikai gyakorlatunkat is.

\section{JEGYZETEK}

Érdeméül legyen mondva, Sen kétségtelenül megpróbálta a fejlôdô országok problémáit, a szegénység kérdését tematikává tenni a közgazdaságtanban. Késôn is kapta meg érte az elismerést, a Nobel-díjat. Általában hamarabb díjazzák a bizottságban a pénzcsinálás tudományát, mint a közjó kutatását. Gunnar Myrdal is idôs volt, amikor megkapta a díjat. Pedig az élet - mint Robert C. Mertonnál - gyakran elég 


\section{Botos Katalin: A koronavírus-válság és a világ régiói}

hamar bebizonyította, hogy az elmélet olykor nem állja ki a gyakorlat próbáját. Amartya Sen egyébként indiai állampolgár maradt egész életében, és nemcsak Amerikában és Angliában, de Indiában is folyamatosan tanított és tanít. Tisztelet neki.

2 Ellen Brown amerikai jogász, író, közéleti aktivista, a public banking szorgalmazója.

3 Fiscal 50: State Trends and Analysis. PEW Analysis, www.pewtrusts.org/en/research-and-analysis/data-visualizations/2014/fiscal-50\#ind0.

4 Jim Bianco on Policy Responses to the Coronavirus: Details, Implications, and Concerns Moving Forward. The post-virus economy faces possibility of higher inflation, threats to Fed independence, and increased pressure on the European Union. In: Macro Musings (ez egy új csatorna az USA-ban, amely makrogazdasági témákkal foglalkozik, közérthetôen).

5 Legutóbb Stiglitz, 2019.

6 Az USA alapvetően, 70\%-ban keresztény, túlsúlyban protestáns felekezeteket követô ország. Ez a huszadik század második feléig mindenképpen az 50 tagállamot összekötô, közös vonás volt, ami az állam és egyház határozott szétválasztása után is jellemzô maradt. A katolikusok aránya 20\% körüli. Egyetlen elnökük volt katolikus, J. F. Kennedy. Az államok között a vallásfelekezetek szerinti különbség elég markáns. Pennsylvaniát a kvékerek alapították, Utah állam a mormonok fố központja. Az USA-ban él az Izraelen kívüli legnagyobb zsidó közösség is. Nyilván a bevándorlás kialakított más vallásokat követô népességcsoportokat is, ezek számaránya azonban kicsi. A vallásos elkötelezôdés a millennium után születetteknél azonban gyengült (Erin Duffin: Religious affiliation in the United States by age. Statista, 2017).

7 Fact check on the EU budget, 2018.

8 EU press release, 27 May 2020.

\section{FELHASZNÁLT IRODALOM}

Botos Katalin (2016): Pénzteremtés a modern gazdaságban. Pénzügyi Szemle, 61. évf., 4. sz., 456-470.

Brown, Ellen (2020): Was the Fed Just Nationalized? The Web of Debt, 3 April.

EC (2020): EU Budget for Recovery: Questions and Answers on REACT-EU, Cohesion Policy Post-2020 and the European Social Fund. European Commission.

EP (2020): The Economy and Coronavirus: Weekly Picks. European Parliament, 20 April, https:/ /www.europarl. europa.eu/RegData/etudes/BRIE/2020/645738/IPOL_BRI(2020)645738_EN.pdf.

Ghosh, Jayati (2020): Messages from „Fiscal Space”. Project Syndicate, 13 May.

Pistor, Katharina (2019): The Code of Capital. Princeton University Press, https://doi.org/10.1515/ 9780691189437.

Portfolio.hu (2020): EU-csúcs: megvan a megállapodás! Portfolio.hu, július 21., www.portfolio.hu/unios-forrasok/20200721/eu-csucs-megvan-a-megallapodas-441638.

Rajan, Raghuram G. (2011): Fault Lines. How Hidden Fractures Still Threaten the World Economy. Princeton University Press, Princeton.

Rajan, Raghuram G. (2017): I Do What I Do. Harper Collins Publisher, India.

Stiglitz, Joseph E. (2013): The Price of Inequality. Norton\&Norton, https://doi.org/10.1111/npqu.11358.

Stiglitz, Joseph E. (2015): The Great Divide. W. W. Norton, New York.

Stiglitz, Joseph E. (2019): People, Power and Profits. W. W. Norton, New York.

The Economic Times (2020): What Matters Most is Health of Real Economy, Not Fiscal Deficit: Rajan. The Economic Times, 25 April, https://economictimes.indiatimes.com/markets/stocks/news/india-hasto-focus-on-lives-as-well-as-livelihood-raghuram-rajan/articleshow/75355261.cms?utm_source=contentofinterest\&utm_medium=text\&utm_campaign=cppst.

The Economist (2020): Sovereign Debt Crises Are Coming. The Economist, Economic Intelligence Unit, May, www.eiu.com/n/campaigns/sovereign-debt-crises-are-coming/.

Turner, Adair (2016): Between Debt and the Devil. Money, Credit, and Fixing Global Finance. Princeton University Press, Princeton. 